\title{
Erythrocyte Na,K Pump in Uremia Acute Correction of a Transport Defect by Hemodialysis
}

\author{
Hiroko Izumo, Seigo Izumo, Mario DeLuise, \\ and Jeffrey $\mathbf{S}$. Flier \\ Charles A. Dana Research Institute and the Harvard-Thorndike \\ Laboratory of Beth Israel Hospital, Department of Medicine, \\ Beth Israel Hospital and Harvard Medical School, Boston, \\ Massachusetts 02215
}

bstract. We studied the erythrocyte $\mathrm{Na}, \mathrm{K}$ pump in chronically hemodialyzed uremic patients, immediately before and after a 4-h period of hemodialysis. Using $\left[{ }^{3} \mathrm{H}\right]$ ouabain as a probe, the number of $\mathrm{Na}, \mathrm{K}$-pump units per erythrocyte did not differ in uremic and control subjects, and hemodialysis had no acute effect on this parameter. In contrast, in these same cells the mean level of $\mathrm{Na}, \mathrm{K}$-pump-mediated ${ }^{86} \mathrm{Rb}$ transport was $30 \%$ lower in predialysis uremic patients than in controls, and this diminution in the rate of ${ }^{86} \mathrm{Rb}$ transport per pump unit was improved after $4 \mathrm{~h}$ of hemodialysis in 17 of 18 subjects. The results of in vitro incubation of normal cells with pre- and post-dialysis sera from uremic patients suggested that a serum factor is responsible for the observed inhibition of $\mathrm{Na}, \mathrm{K}$-pump activity. Changes in cell $\mathrm{Na}$ concentration during dialysis did not appear to be responsible for the increased rate of $\mathrm{Na}, \mathrm{K}$-pump turnover after hemodialysis. However, there was a significant correlation between the extent of rise in pump-mediated ${ }^{86} \mathrm{Rb}$ uptake and the weight loss that occurred during dialysis.

We conclude that the ion transport turnover rate of the erythrocyte $\mathrm{Na}, \mathrm{K}$-pump is impaired in uremia by a nonouabain like circulating factor. This factor, whose activity is diminished acutely by hemodialysis, may play an important role in the systemic manifestations of the uremic syndrome, and could be an important endogenous regulator of the $\mathrm{Na}, \mathrm{K}-\mathrm{ATPase}$.

An abstract of this work was presented at the American Federation for Clinical Research Meeting in May 1983.

Received for publication 11 October 1983 and in revised form 29 March 1984.

J. Clin. Invest.

(c) The American Society for Clinical Investigation, Inc. $0021-9738 / 84 / 08 / 0581 / 08 \quad \$ 1.00$

Volume 74, August 1984, 581-588

\section{Introduction}

The Na,K-ATPase is the enzymatic equivalent of the $\mathrm{Na}, \mathrm{K}$ pump (1-3), and as such, it has many critical functions, including maintenance of cellular $\mathrm{Na}$ and $\mathrm{K}$ concentrations and establishment of transmembrane electrochemical gradients. The possibility that there might be important abnormalities at the level of the membrane Na,K-ATPase in patients with chronic renal failure (CRF) ${ }^{1}$ was first suggested nearly $20 \mathrm{yr}$ ago, with the pioneering studies of Welt et al. (4). Using the $\mathrm{Na}, \mathrm{K}-\mathrm{ATPase}$ of erythrocyte membranes as a model system, these workers found abnormalities of this enzyme-transport system in a subgroup $(\sim 25 \%)$ of patients with CRF. The abnormalities present in these patients included: $(a)$ increased cell $\mathrm{Na}$ concentration; $(b)$ reduced membrane $\mathrm{Na}, \mathrm{K}-\mathrm{ATPase}$ enzymatic activity; and $(c)$ reduced rate constant for $\mathrm{Na}$ efflux via the $\mathrm{Na}, \mathrm{K}$ pump. Further, these patients had a factor in plasma that, upon exposure to normal cells, could reduce subsequently measured $\mathrm{Na}, \mathrm{K}-\mathrm{ATPase}$ activity and pump-mediated $\mathrm{Na}$ efflux (5). Finally, in very limited studies, the defect was seen to be diminished after chronic dialysis (6).

Over the subsequent years, abnormalities involving the erythrocyte $\mathrm{Na}, \mathrm{K}-\mathrm{ATPase}$ have been described in several other groups of CRF patients (7-11) and alterations in Na,K-ATPase enzyme or transport activity have been seen in leukocytes (12, 13), muscle cells (14), intestine (15), and brain (16) in CRF as well. However, despite the potential importance of a defect at the level of $\mathrm{Na}, \mathrm{K}-\mathrm{ATPase}$ in the genesis of uremia, a clear understanding of the nature of the abnormality and its correction by hemodialysis has not emerged. At least two reasons for this are apparent. First, and most obvious, is heterogeneity of patient groups, since patients with varying degrees of renal failure have been studied, both before and after institution of dialysis. A second, and more subtle problem has been heterogeneity of the methods used to study the Na,K-ATPase. This problem arises from the fact that there are several different ways in which the $\mathrm{Na}, \mathrm{K}-\mathrm{ATPase}$ can be probed, including $(a)$ the specific binding of the inhibitory ligand $\left[{ }^{3} \mathrm{H}\right]$ ouabain, which can be used to

1. Abbreviations used in this paper: BUN, blood-urea nitrogen; CRF, chronic renal failure; HD, hemodialysis. 
determine the number of $\mathrm{Na}, \mathrm{K}$ pump units; $(b)$ the activity of membrane $\mathrm{Na}, \mathrm{K}-\mathrm{ATPase}$ as a function of varying concentrations of substrates and ions, which measures the enzymatic function of the protein; and $(c)$ the rates of specific Na,K-ATPase-mediated transport of $\mathrm{Na}$ and/or $\mathrm{K}$ across cell membranes, which assess the transport function of the enzyme-pump.

In this study, we have combined measurements of the number of $\left[{ }^{3} \mathrm{H}\right]$ ouabain binding sites (taken to be equivalent to the number of $\mathrm{Na}, \mathrm{K}$ pump units) and measurements of ${ }^{86} \mathrm{Rb}$ uptake in order to gain a clearer insight into the status of the erythrocyte $\mathrm{Na}, \mathrm{K}-\mathrm{ATPase}$ in chronic renal failure. Further, we have studied the effect of acute hemodialysis upon these parameters.

\section{Methods}

Subjects. We studied 13 patients ( 9 men and 4 women) with CRF of varying etiologies, aged from 17 to $80 \mathrm{yr}$ old with an average age of 50 yr. They had been on chronic hemodialysis for 2 wk to 23 mo with a mean duration of $11.4 \mathrm{mo}$. None of the patients were taking digitalis or diuretics, had liver function abnormalities, or had received blood transfusions during the past $13 \mathrm{~d}$. Five of the patients were studied twice. 24 normal controls ( 8 female, 16 male) were studied. They were $21-$ $45 \mathrm{yr}$ old with a mean age of $31.3 \mathrm{yr}$.

Studies of $N a, K$ pump status. $\left[{ }^{3} \mathrm{H}\right]$ ouabain binding and ${ }^{86} \mathrm{Rb}$ uptake were measured by a minor modification of a previously described technique (17). $10 \mathrm{~cm}^{3}$ of blood was drawn from each subject into a heparinized syringe at the start of each hemodialysis and immediately after a 4-h period of hemodialysis. The same amount of blood was drawn from controls. The plasma and buffy coat layers were separated by centrifugation and the erythrocytes were washed three times with 10 vol of ice cold, isoosmotic, $112 \mathrm{mM} \mathrm{MgCl}$ solution. After a final wash in ouabain binding buffer $\left(140 \mathrm{mM} \mathrm{NaCl}, 1 \mathrm{mM} \mathrm{CaCl}_{2}, 1 \mathrm{mM} \mathrm{MgCl}\right.$, $5 \mathrm{mM}$ dextrose, and $20 \mathrm{mM}$ Hepes, $\mathrm{pH} 7.40$ ), the cells were suspended in this buffer at a hematocrit of 5-10\%. To measure ouabain binding, triplicate $200-\mu \mathrm{l}$ aliquots of the cell suspension were added to $0.5-1$ pmol of $\left[{ }^{3} \mathrm{H}\right]$ ouabain (New England Nuclear, Boston, MA; $18 \mathrm{Ci} / \mathrm{mM}$ sp act) and unlabeled ouabain so that the total ouabain concentration ranged from 2.5 to $100 \mathrm{nM}$, as indicated in each figure legend, in a total volume of $250 \mu \mathrm{l}$. Nonspecific binding was measured in the presence of $0.1 \mathrm{mM}$ unlabeled ouabain. After a 60 -min incubation at $37^{\circ} \mathrm{C}$ in a shaking water bath, the cells were washed three times in 1-ml volumes of ice-cold, $112 \mathrm{mM} \mathrm{MgCl} .200 \mu \mathrm{l}$ of $5 \%(\mathrm{wt} / \mathrm{vol})$ trichloroacetic acid were added, and the eluted radioactivity was counted in $5 \mathrm{ml}$ Biofluor in a liquid scintillation counter (G. D. Searle \& Co., Skokie, IL). Specific binding sites were saturated by $100 \mathrm{nM}$ concentrations of ouabain in both control and renal failure patients before and after dialysis. Accordingly, we used the values for specific ouabain binding at $100 \mathrm{nM}$ concentrations to determine specific ouabain binding in Figs. 2, 5, 6, and 8.

To measure the cation transport function of the $\mathrm{Na}, \mathrm{K}$ pump, cells from the same samples as above were, after the three $\mathrm{MgCl}_{2}$ washes, resuspended in "ouabain binding buffer" supplemented with $4 \mathrm{mM} \mathrm{KCl}$ and the $\mathrm{K}$ analogue ${ }^{86} \mathrm{RbCl} ; \sim 100,000 \mathrm{cpm} / 250 \mu \mathrm{l}$ of final volume were added. To enable measurement of specific pump-mediated transport, paired tubes were incubated in the absence and presence of $0.1 \mathrm{mM}$ ouabain. The specific Na,K-ATPase-mediated uptake of ${ }^{86} \mathrm{Rb}$ was calculated as the difference between total radioactivity taken up by triplicate aliquots of the cells alone and that taken up in the presence of ouabain.
After a 15 -min incubation at $37^{\circ} \mathrm{C}$ in a shaking water bath, cells were washed with ice-cold $112 \mathrm{mM} \mathrm{MgCl}$, intracellular radioactivity was released by $5 \%$ trichloroacetic acid, and Cerenkov radiation was counted. Cell counts were performed by using a hemocytometer.

In vitro incubation of normal cells with pre-and post-dialysis serum. Erythrocytes from healthy control subjects were obtained and washed as above, and then incubated with $\mathrm{ABO}$ and $\mathrm{Rh}$ matched sera from controls or CRF patients (pre- and post-dialysis). Incubation was carried out for $3 \mathrm{~h}$ in room air at $37^{\circ} \mathrm{C}$ in a shaking water bath at a hematocrit of $30 \%$. No visible hemolysis occurred. After incubation, cells were washed with $112 \mathrm{mM} \mathrm{MgCl}$ as above, and ouabain binding and pumpmediated ${ }^{86} \mathrm{Rb}$ uptake were assessed as described above.

Other measurements. Plasma $\mathrm{Na}$ and $\mathrm{K}$ concentrations and $\mathrm{pH}$ were measured using a pH/blood gas analyzer and an $\mathrm{Na} / \mathrm{K}$ analyzer, System 502 (Instrumentation Laboratory, Lexington, MA). Blood-urea nitrogen (BUN) and creatinine were measured on an autoanalyzer, Technicon Smac. For intracellular electrolyte measurement, cells were washed three times with $112 \mathrm{mM} \mathrm{MgCl}$. A $500 \mu \mathrm{l}$ of erythrocyte suspension was removed into microtubes and centrifuged for $1 \mathrm{~min}$ at $10,000 \mathrm{~g}$ in a microfuge (Beckman Instruments, Inc., Fullerton, CA). The supernatant and top layer of cells were removed, and a 200- $\mu$ l aliquot of cells was obtained with a wide-bore pipette tip and added to $9.8 \mathrm{ml}$ of doubledistilled water. Sodium and potassium levels were subsequently measured with an atomic absorption spectrophotometer (Perkin-Elmer Corp., Norwalk, CT), and the results are expressed as millimoles of cation per liter of cells, as well as on a per cell basis. Serum immunoassay for digoxin was performed with a coated tube ${ }^{125}$ I-digoxin radioimmunoassay kit (Clinical Assays, Cambridge, MA).

Hemodialysis. Either of two commercially available dialyzers was used (CDBE PPD with surface area 1.3 or $1.6 \mathrm{M}^{2}$ or Terumo TE with surface area 1.0 or $1.5 \mathrm{M}^{2}$ ). Both were equipped with Cuprophan membranes, 11 or $13 \mu \mathrm{m}$. The hemodialysis bath composition was as follows: sodium, $134 \mathrm{meq} / \mathrm{liter}$ calcium, $2.5 \mathrm{meq} / \mathrm{liter}$; potassium, $2.5 \mathrm{meq} / \mathrm{liter}$; magnesium, $1.5 \mathrm{meq} / \mathrm{liter}$; chloride, $104 \mathrm{meq} / \mathrm{liter}$; acetate, $36.6 \mathrm{meq} /$ liter; and dextrose, $200 \mathrm{mg} / 100 \mathrm{ml}$ (Baxter Travenol Laboratories, Deerfield, IL).

Each 4-h dialysis session included hemodialysis and a variable amount of ultrafiltration. The latter was determined by a clinical assessment of the volume status of the patient.

Statistical methods. Statistical analysis was used using the paired $t$ test for within group comparisons, and the unpaired $t$ test for comparisons between groups.

\section{Results}

Binding of $\left[{ }^{3} \mathrm{H}\right]$ ouabain to human erythrocytes is a high affinity, saturable process (18), and the receptor for $\left[{ }^{3} \mathrm{H}\right]$ ouabain in this, as in other cells, is the $\mathrm{Na}, \mathrm{K}-\mathrm{ATPase}$ enzyme. Under the conditions used in these experiments, the number of $\left[{ }^{3} \mathrm{H}\right]$ ouabain binding sites is determined at saturating concentrations of the ligand, at which $\mathrm{Na}, \mathrm{K}$ pump-mediated ion transport is completely inhibited (19). This is true both in cells from control (19) and CRF patients (Fig. 1).

Fig. 2 shows the values for saturable ouabain binding to erythrocytes of control subjects, and CRF patients before and after $4 \mathrm{~h}$ of hemodialysis. In each group, saturable ouabain binding is seen to vary over a three- to fourfold range, as seen in studies of erythrocyte ouabain binding in other patient groups 


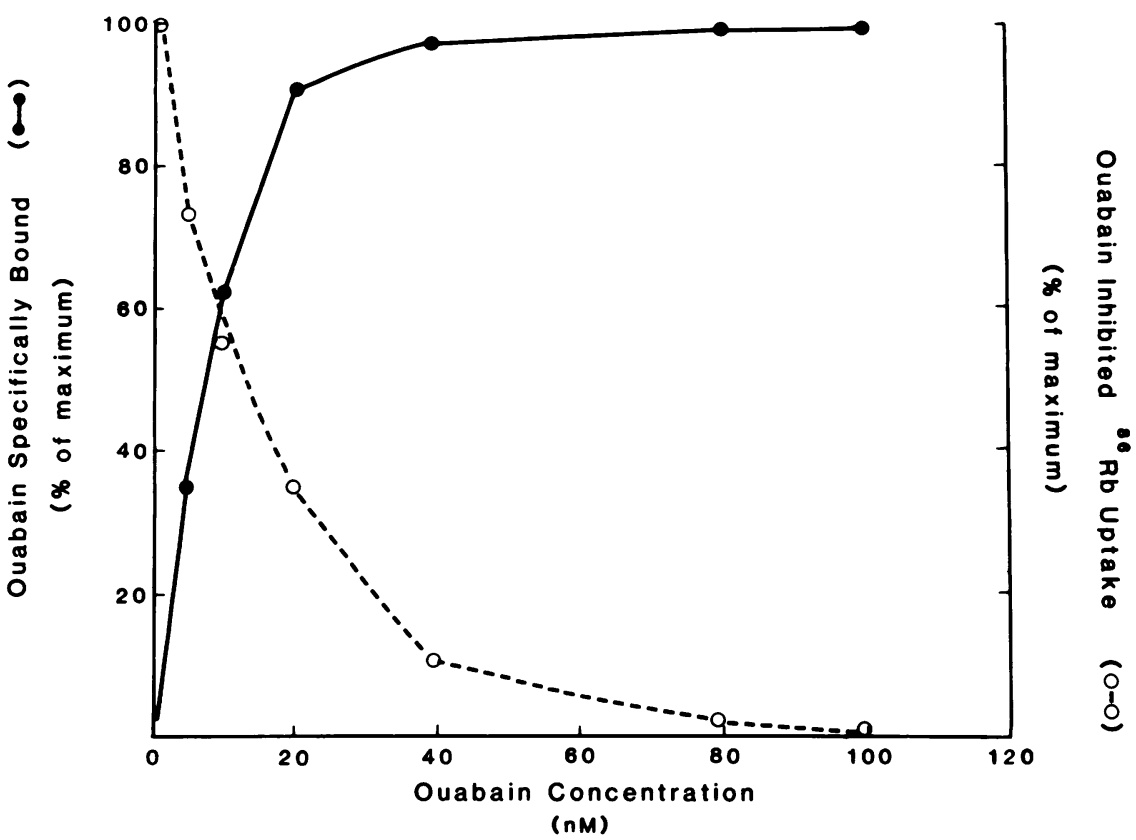

Figure 1. Comparison of specific ouabain binding and $\mathrm{Na}, \mathrm{K}$-pump-mediated ${ }^{86} \mathrm{Rb}$ uptake in erythrocytes of a patient with renal failure before dialysis. Methods are as described. Saturation of binding sites and complete inhibition of pump activity are both achieved by $1 \mathrm{~h}$ at $37^{\circ} \mathrm{C}$ with ouabain concentrations between 80 and $100 \mathrm{nM}$.
(17). In 24 control subjects, the mean erythrocyte ouabain binding capacity was $0.512 \pm 0.12 \mathrm{pmol} / 10^{9}$ cells. This value was slightly, but not significantly higher than that of CRF patients

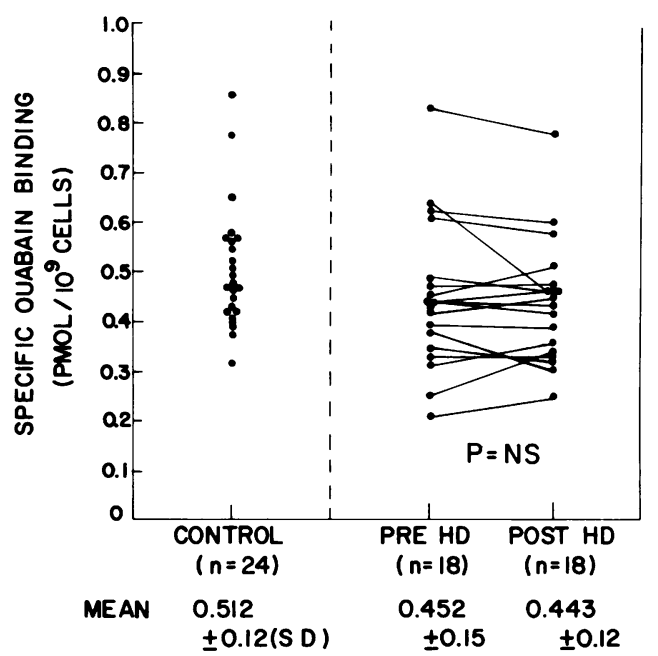

Figure 2. Specific ouabain binding capacity of erythrocytes of control subjects and CRF patients pre- and post-dialysis. Individual values for ouabain binding capacity of erythrocytes from control and CRF patients were obtained before and after hemodialysis (HD). Ouabain binding capacity was determined by using a total (i.e., labeled and unlabeled) ouabain concentration of $100 \mathrm{nM}$, after subtracting nonspecific binding. The mean value for ouabain binding capacity was slightly but not significantly lower in CRF patients $(0.452 \pm 0.15)$ than in controls $(0.512 \pm 0.12, P<0.1)$ and was not changed postdialysis $(0.443 \pm 0.13, P=\mathrm{NS})$. immediately before dialysis, i.e., $0.452 \pm 0.15 \mathrm{pmol} / 10^{9}$ cells $(P$ = NS). Ouabain binding capacity pre- and post-dialysis were nearly identical $\left(0.452 \pm 0.15\right.$ vs. $0.443 \pm 0.12 \mathrm{pmol} / 10^{9}$ cells, $P$ $=$ NS). Thus, specific ouabain binding capacity, which reflects the number of $\mathrm{Na}, \mathrm{K}$ pump units, was slightly but not significantly lower in this group of CRF patients than in controls, and $4 \mathrm{~h}$ of hemodialysis in CRF patients had no significant effect upon this parameter.

In contrast to these findings for $\mathrm{Na}, \mathrm{K}$ pump number (i.e., saturable ouabain binding), erythrocytes from the same CRF patients had a reduced rate of pump-mediated ${ }^{86} \mathrm{Rb}$ uptake when compared with control (Fig. 3, left). Thus, the mean rate of pump-mediated ${ }^{86} \mathrm{Rb}$ uptake was $139.23 \pm 22.37 \mathrm{nM} / 10^{9}$ cells per $h$ in controls and $104.99 \pm 24.13 \mathrm{nM} / 10^{9}$ cells per $\mathrm{h}$ in CRF patients before dialysis, which represents a mean reduction of $30 \%$ (Fig. 3, left). Pump-independent ${ }^{86} \mathrm{Rb}$ uptake was not significantly different in patients and controls $(52.84 \pm 14.39$ vs. $60.56 \pm 17.86 \mathrm{nM} / 10^{9}$ cells per $\mathrm{h}, P=\mathrm{NS}$ ) (Fig. 3 , right).

Unlike ouabain binding, which was unaffected by dialysis (Fig. 2), pump-mediated ${ }^{86} \mathrm{Rb}$ uptake was acutely increased after hemodialysis in these patients (Fig. 4, left). Pump-mediated ${ }^{86} \mathrm{Rb}$ uptake was $104.99 \pm 24.13 \mathrm{nM} / 10^{9}$ cells per $\mathrm{h}$ predialysis, and $124.90 \pm 27.72 \mathrm{nM} / 10^{9}$ cells $/ \mathrm{h}$ after $4 \mathrm{~h}$ of dialysis. In addition to this significant mean $20 \%$ difference in pump activity $(P$ $<0.001$ ), it is seen that the rate of pump-mediated ${ }^{86} \mathrm{Rb}$ uptake rose in 17 of 18 studies. The degree of rise ranged from $3 \%$ to as much as $50 \%$ and the mean delta pump activity was $+21 \%$ $(P<0.001)$. Hemodialysis had a variable effect on the pumpindependent ${ }^{86} \mathrm{Rb}$ uptake (Fig. 4, right), but there was no significant change in the mean level of this parameter as a result of dialysis. 


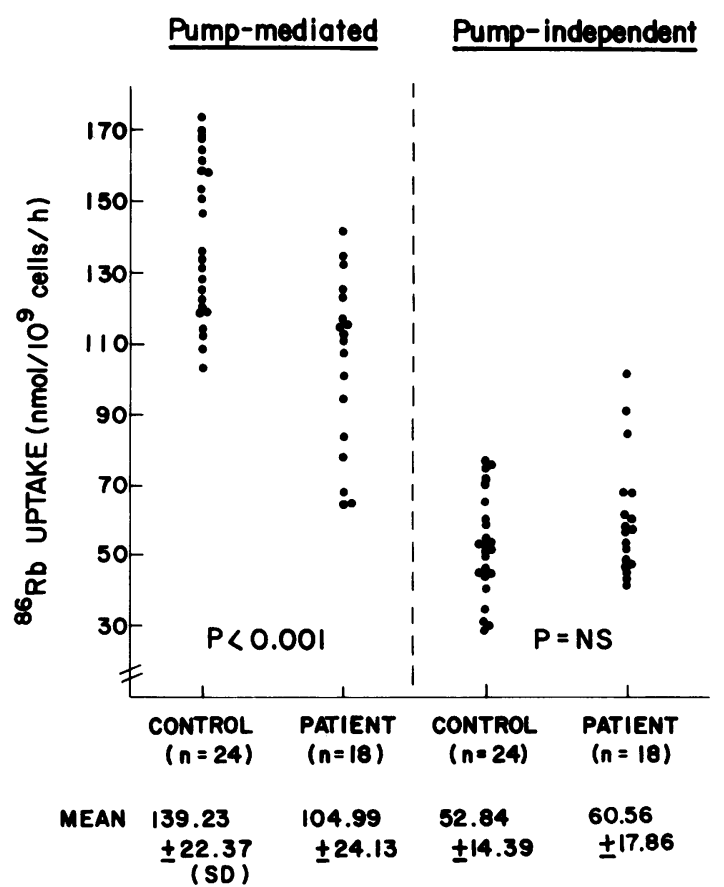

Figure 3. Pump-mediated and pump-independent ${ }^{86} \mathrm{Rb}$ uptake in control and CRF patients. The mean level of pump-mediated ${ }^{86} \mathrm{Rb}$ uptake (left) was $139.23 \pm 22.37 \mathrm{mM} / 10^{9}$ cells in control cells and $104.99 \pm 24.13$ in CRF cells before dialysis, a $30 \%$ mean difference. The mean level of pump-independent ${ }^{86} \mathrm{Rb}$ uptake (right) was not significantly different in patients and controls $(52.84 \pm 14.39$ vs. $60.56 \pm 17.86 \mathrm{mM} / 10^{9}$ cells $/ \mathrm{h}, P=\mathrm{NS}$ ).

To better illustrate the nature of the abnormality in $\mathrm{Na}, \mathrm{K}$ pump function, we have graphed individual values for $\left[{ }^{3} \mathrm{H}\right]$ ouabain binding as a function of pump-mediated ${ }^{86} \mathrm{Rb}$ uptake in control and CRF patients before dialysis (Fig. 5), and in CRF patients pre- and post-dialysis (Fig. 6). In each situation, there is a positive correlation between the number of $\left[{ }^{3} \mathrm{H}\right]$ ouabain binding sites and pump-mediated ${ }^{86} \mathrm{Rb}$ uptake: i.e., $r=0.726$, $P<0.002$ in control, $r=0.722, P<0.002$ predialysis, and $r$ $=0.541, P<0.05$ postdialysis. This confirms previous findings from our (17) and other laboratories $(20,21)$. However, it is evident that the correlation line is shifted downward in predialysis renal failure patients when compared with controls (Fig. 5). Thus, at any given level of ouabain binding, which reflects the number of $\mathrm{Na}, \mathrm{K}$ pump units, there is less pump-mediated ${ }^{86} \mathrm{Rb}$ uptake in CRF patients before dialysis. This suggests that $\mathrm{Na}, \mathrm{K}$ pump units are pumping ${ }^{86} \mathrm{Rb}$ less efficiently in CRF patients before dialysis. It is also evident that dialysis was associated with an acutely increased rate of pump-mediated ${ }^{86} \mathrm{Rb}$ uptake at an unchanged level of specific ouabain binding, so that the correlation line between these two parameters returned towards that of controls (Fig. 6). Taken together, these data suggest that

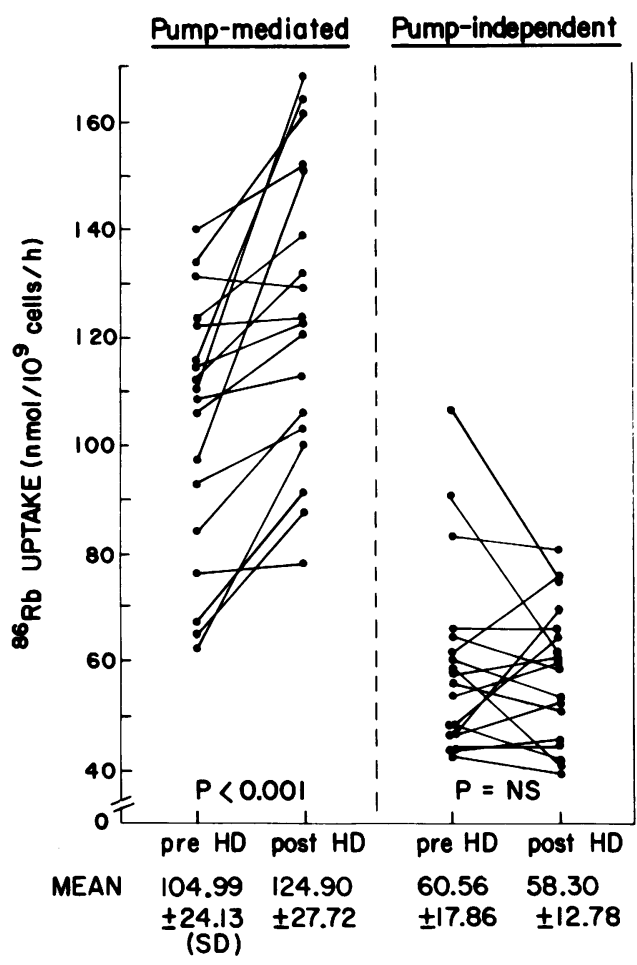

Figure 4. Acute effect of hemodialysis on pump-mediated and pumpindependent ${ }^{86} \mathrm{Rb}$ uptake into erythrocytes. The effect of $4 \mathrm{~h}$ of hemodialysis upon pump-mediated (left) and pump-independent (right) ${ }^{86} \mathrm{Rb}$ uptake into erythrocytes of CRF patients. The mean rise in pump-mediated ${ }^{86} \mathrm{Rb}$ uptake after dialysis was $20 \%(P<0.001)$.

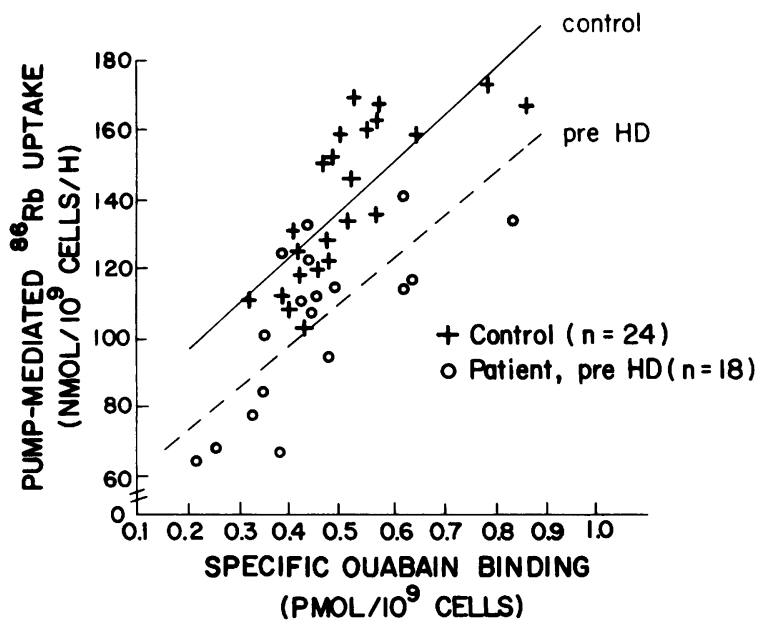

Figure 5. Correlation between specific ouabain binding capacity and pump-mediated ${ }^{86} \mathrm{Rb}$ uptake in erythrocytes of control and CRF patients. The correlation line between specific ouabain binding capacity and pump-mediated ${ }^{86} \mathrm{Rb}$ uptake is shifted downward in predialysis renal failure patients when compared with controls. 


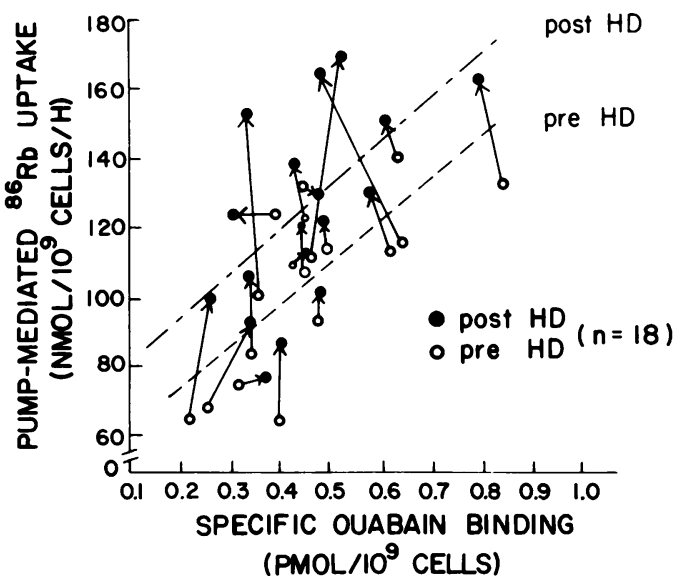

Figure 6. Correlation between specific ouabain binding capacity and pump-mediated ${ }^{86} \mathrm{Rb}$ uptake in CRF patients pre- (- - ) and post$(-\cdot-\cdot-)$ hemodialysis. Arrows connect values for each patient pre(o) and post- (๑) hemodialysis.

hemodialysis may remove a factor that inhibits $\mathrm{Na}, \mathrm{K}$ pumpmediated ${ }^{86} \mathrm{Rb}$ influx.

The mean values for cellular $\mathrm{Na}$ concentration were $5.38 \pm 1.20 \mathrm{meq} /$ liter of cells in controls, $5.77 \pm 1.78 \mathrm{meq} / \mathrm{liter}$ of cells in predialysis CRF patients, and $6.15 \pm 1.40 \mathrm{meq} / \mathrm{liter}$ of cells in postdialysis patients. These values are not significantly different, although two patients with CRF had values for intracellular $\mathrm{Na}$ that were higher than any controls (10.2 and 10.4 $\mathrm{meq} / \mathrm{liter}$ of cells). Since the intracellular $\mathrm{Na}$ concentration is an important regulator of the rate of $\mathrm{Na}, \mathrm{K}$ pump turnover, we attempted to determine whether the degree to which pump activity increased after dialysis was a function of the initial intracellular sodium concentration, and no significant correlation between these two parameters was found $(r=0.157)$. Furthermore, there was no significant correlation between the extent of rise in pump-mediated ${ }^{86} \mathrm{Rb}$ uptake after dialysis and any change (either a rise or fall) in the cell $\mathrm{Na}$ concentration ( $r$ $=0.132$ ) (Fig. 7). This is true whether $\mathrm{Na}$ is expressed per liter of cells or per $10^{9}$ cells (data not shown). These data suggest that the increase in pump-mediated ${ }^{86} \mathrm{Rb}$ uptake seen after dialysis was not caused by a rise in the intracellular concentration of sodium.

Table I summarizes the mean values of several parameters that were measured pre- and post-hemodialysis. The extent to which pump activity increased did not correlate with serum levels of $\mathrm{Na}, \mathrm{K}, \mathrm{pH}, \mathrm{BUN}$ or creatinine before or after dialysis. However, there was a significant correlation between the extent of rise in pump-mediated ${ }^{86} \mathrm{Rb}$ uptake and the weight loss that occurred during the course of dialysis $(r=0.517, P=0.02)$ (Fig. 8). Thus, the greatest rise in ${ }^{86} \mathrm{Rb}$ transport was seen in those individuals who lost the most weight during hemodialysis.

We also performed a digoxin radioimmunoassay with these sera to assess the possibility that some patients might have been

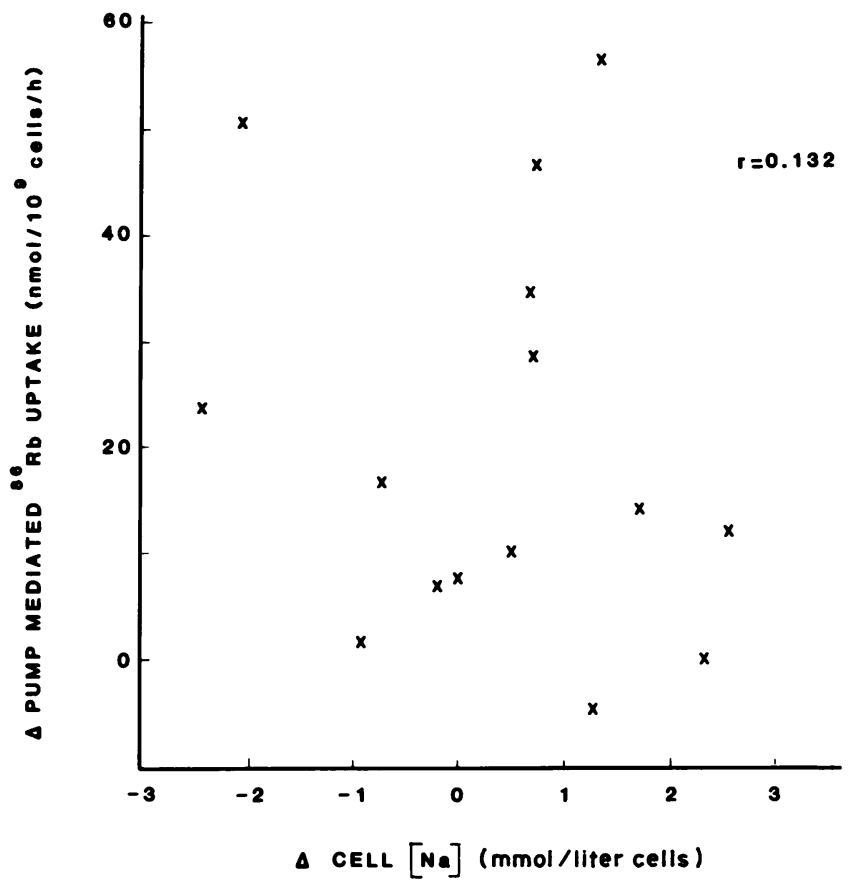

Figure 7. Correlation between the change in erythrocyte $\mathrm{Na}$ concentration during dialysis and the change in pump-mediated ${ }^{86} \mathrm{Rb}$ uptake during dialysis in 15 subjects.

exposed to digitalis, or that an endogenous digitalis-like molecule with cross-reactivity in this assay (22) might be present. There was no significant displacement in the digitalis radioimmunoassay by any sera from controls, predialysis CRF patients, or postdialysis CRF patients (data not shown).

Finally, we attempted to determine whether the apparent inhibition of pump activity that predialysis cells manifested was mediated by a factor present in predialysis serum. Fig. 9 shows the specific ouabain binding and pump-mediated ${ }^{86} \mathrm{Rb}$ uptake of normal erythrocytes after exposure to sera removed from patients either pre- or postdialysis. The level of $\left[{ }^{3} \mathrm{H}\right]$ ouabain binding was the same after cells were exposed to pre- or postdialysis serum. In contrast, pump-mediated ${ }^{86} \mathrm{Rb}$ uptake was lower in cells exposed to predialysis serum than in cells exposed to postdialysis serum. The mean difference was $22.6 \%(n=9$, $P<0.01)$. In two experiments, normal cells exposed to postdialysis sera had a level of pump activity equal to the level seen after exposure of the cells to normal serum (data not shown). This suggests the existence of a serum factor in predialysis CRF patients that is capable of inhibiting $\mathrm{Na}, \mathrm{K}$ pump activity.

\section{Discussion}

Since the pioneering studies of Welt et al. (4), there has been considerable interest in the possibility that chronic renal failure may lead to physiologically important abnormalities in the function of the Na,K-ATPase enzyme-pump. Although studies 
Table I. Mean Value of Several Parameters Measured Pre- and Post-Hemodialysis

\begin{tabular}{|c|c|c|c|}
\hline & $\begin{array}{l}\text { Control } \\
(n=24)\end{array}$ & $\begin{array}{l}\text { Pre-HD } \\
(n=18)\end{array}$ & $\begin{array}{l}\text { Post-HD } \\
(n=18)\end{array}$ \\
\hline Specific ouabain binding ( $p m o l / 10^{9}$ cells $)$ & $0.512 \pm 0.12$ & $0.452 \pm 0.15$ & $0.443 \pm 0.12$ \\
\hline \multicolumn{4}{|l|}{${ }^{86} \mathrm{Rb}$ uptake $\left(\mathrm{nmol} / 10^{4} \mathrm{cells}\right)$} \\
\hline Pump-mediated & $139.23 \pm 22.37$ & $104.99 \pm 24.13$ & $124.90 \pm 27.72$ \\
\hline Pump-independent & $52.84 \pm 14.39$ & $60.56 \pm 17.86$ & $58.30 \pm 12.78$ \\
\hline \multicolumn{4}{|c|}{$\begin{array}{l}\text { Change in ouabain inhibitable }{ }^{86} \mathrm{Rb} \text { uptake }(\%) \text { : } \\
\text { post- vs. pre-dialysis (mean of changes in }\end{array}$} \\
\hline \multicolumn{4}{|l|}{ Intracellular } \\
\hline $\mathrm{Na}($ meq/liter cells $)$ & $5.38 \pm 1.20$ & $5.77 \pm 1.78$ & $6.16 \pm 1.40$ \\
\hline $\mathrm{K}$ (meq/liter cells) & $87.8 \pm 8.8$ & $82.7 \pm 16.2$ & $78.9 \pm 15.6$ \\
\hline \multicolumn{4}{|l|}{ Serum } \\
\hline $\mathrm{Na}($ meq/liter cells $)$ & $141.5 \pm 6.5$ & $140.5 \pm 3.1$ & $144.1 \pm 4.0$ \\
\hline $\mathrm{K}$ (meq/liter cells) & $4.25 \pm 0.75$ & $4.22 \pm 1.28$ & $3.05 \pm 0.67$ \\
\hline $\mathrm{pH}$ & $7.40 \pm 0.05$ & $7.38 \pm 0.06$ & $7.45 \pm 0.07$ \\
\hline BUN $(m g / d l)$ & $14.6 \pm 6.0$ & $61.4 \pm 29.5$ & $30.0 \pm 13.7$ \\
\hline Creatinine $(m g / d l)$ & $0.65 \pm 0.65$ & $10.21 \pm 3.19$ & $4.57 \pm 1.59$ \\
\hline
\end{tabular}

with erythrocytes (4-11), leukocytes $(12,13)$, and muscle (14) have produced a consensus that some abnormality at the level of $\mathrm{Na}, \mathrm{K}-\mathrm{ATPase}$ exists in many patients, the nature of the abnormality and its frequency in defined populations have remained unclear. Variations in patient populations and in methods used to study the $\mathrm{Na}, \mathrm{K}-\mathrm{ATPase}$ may be responsible for this fact.

In the current study, we have used several means to assess the status of erythrocyte $\mathrm{Na}, \mathrm{K}-\mathrm{ATPase}$ in a group of chronically hemodialyzed patients with chronic renal failure, both before and immediately after hemodialysis. The data indicate that the erythrocytes of these chronically hemodialyzed patients have a specific reduction in the rate of ${ }^{86} \mathrm{Rb}$ uptake mediated by a given (normal) number of $\mathrm{Na}, \mathrm{K}$-pump units. Furthermore, this inhibition in pump turnover is acutely reversed by hemodialysis, and appears, through the results of in vitro incubation studies, to be mediated by a serum factor.

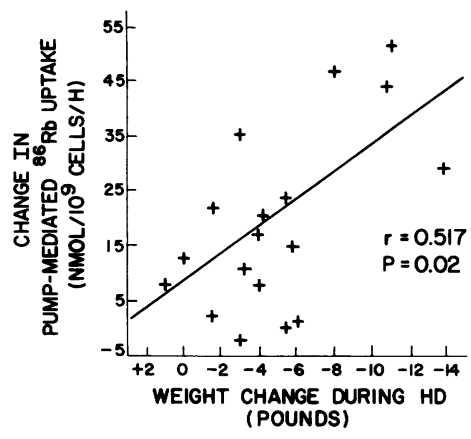

Figure 8. Correlation between rise in pump-mediated ${ }^{86} \mathrm{Rb}$ uptake after dialysis and weight change of patient during dialysis.
Any study of the Na,K-ATPase in disease must take note of the varying methodologies used to probe this complex enzymepump. Determinations of the number of enzyme units must be distinguished from probes of the ion ( $\mathrm{K}$ or $\mathrm{Na}$ ) transport function of the enzyme, and these must in turn be distinguished from assays of the ATPase function of the enzyme. By studying two or more of these parameters in the same cells, greater insight into abnormalities can be gained.

We have used $\left[{ }^{3} \mathrm{H}\right]$ ouabain as a probe to assess the number of $\mathrm{Na}, \mathrm{K}-\mathrm{ATP}$ ase units expressed in erythrocyte membranes (20). This technique is based upon the knowledge that ouabain binds with high affinity and specificity to the $\mathrm{Na}, \mathrm{K}-\mathrm{ATPase}$, with an apparent stoichiometry of $1: 1$. As expected, the level of saturable ouabain binding correlates very well with the maximal $\mathrm{Na}, \mathrm{K}$ ATPase activity in plasma membranes (21), and once bound to ouabain, the activity of the enzyme-pump is completely inhibited. Under the conditions used for $\left[{ }^{3} \mathrm{H}\right]$ ouabain binding in these experiments, the ligand saturates high affinity binding sites in cells of control and CRF patients and completely inhibits pump-mediated $\mathrm{K}$ transport activity (19). Thus, our technique provides a valid index of $\mathrm{Na}, \mathrm{K}$-pump number in these cells.

Using this approach, erythrocytes from these CRF patients did not differ from controls with respect to the level of saturable ouabain binding. Because, under these assay conditions $\left(37^{\circ} \mathrm{C}\right.$, $1 \mathrm{~h}$ ), ouabain concentrations $<40 \mathrm{nM}$ have not reached equilibrium, we cannot perform Scatchard plots to determine the actual affinity of ouabain binding. However, the concentration of ouabain that half-saturates the binding sites at $1 \mathrm{~h}$ should reflect the binding affinity, and this parameter was also the same in CRF patients as in control, i.e., $7 \mathrm{nM}$ (data not shown). 

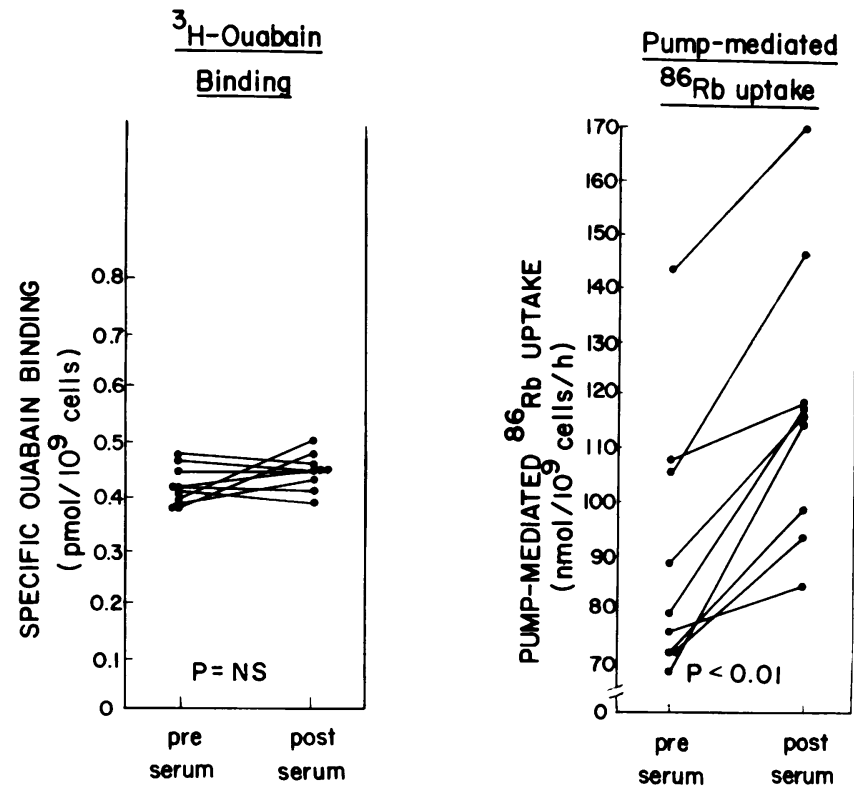

Figure 9. The effect of pre-incubating normal cells with sera obtained pre- and post-hemodialysis $\left(37^{\circ} \mathrm{C}, 3 \mathrm{~h}\right)$ on subsequent specific ouabain binding capacity (left) and pump-mediated ${ }^{86} \mathrm{Rb}$ uptake (right). Whereas ouabain binding capacity did not differ between cells previously exposed to pre- or post-dialysis serum (left), pump-mediated ${ }^{86} \mathrm{Rb}$ uptake was $22.6 \%$ lower in cells exposed to pre- vs. post-dialysis serum (right).

Although of interest, the finding that saturable ouabain binding was the same in CRF and controls should not be overemphasized. First, we did not carefully study the hematologic status of these patients and thus, the number of ouabain binding sites could be influenced by erythrocyte factors apart from any specific regulation of $\mathrm{Na}, \mathrm{K}$ pump density. Second, many of these patients received periodic transfusions over the previous months, and thus, precise quantitation of the patients' $\mathrm{Na}, \mathrm{K}$ pump density by ouabain binding techniques could be subject to some transfusion artifacts. However, the finding of normal ouabain binding is unambiguously important when taken in context with several other observations, most importantly, measurements of pumpmediated ${ }^{86} \mathrm{Rb}$ uptake.

Thus, despite their "normal" number of specific ouabain binding sites, these cells had a clearly reduced rate of pumpmediated ${ }^{86} \mathrm{Rb}$ uptake. The specificity of this effect is suggested by the normal level of pump-independent transport. The nature of this defect in pump-mediated ${ }^{86} \mathrm{Rb}$ transport is best seen when we plot pump-mediated ${ }^{86} \mathrm{Rb}$ transport as a function of specific ouabain binding. It is clear that $\mathrm{Rb}$ transport is a function of pump density in both control and CRF patients, as we have previously shown (17), but that CRF patients before dialysis have a different correlation line between these two parameters. At any pump density, as assessed by ouabain binding, pumpmediated $\mathrm{Rb}$ uptake is reduced.

The effect of $4 \mathrm{~h}$ of hemodialysis upon these parameters adds further strength to our observations. In these experiments, in which each patient serves as his own control, we see that whereas specific ouabain binding was unaffected by dialysis, pump-mediated ${ }^{86} \mathrm{Rb}$ uptake (but not pump-independent uptake) rose after dialysis in 17 of 18 studies. The nearly universal nature of this effect, and its large magnitude in many patients underscore the importance of this observation.

Although a rapid effect of hemodialysis upon the activity of the erythrocyte $\mathrm{Na}, \mathrm{K}$ pump has not previously been observed, there is a precedent for hemodialysis having an acute effect upon an erythrocyte ion transport system. Thus, erythrocyte sodiumlithium countertransport was shown to be acutely influenced by ultrafiltration and hemodialysis in a group of patients with end stage renal disease due to hypertension (23). In this study, in contrast to our own, dialysis acutely decreased the rate of countertransport, an effect postulated to be secondary to removal by dialysis of a necessary cofactor for the sodium-lithium countertransport process. As in our study, exposure of normal cells to pre- or post-dialysis plasma produced coordinate changes in the rate of countertransport (23).

We have taken several approaches to further elucidation of the basis for these effects. Our first approach was to test the hypothesis that the inhibition of pump activity was related to a serum factor. We exposed normal cells to normal serum or to pre- or post-dialysis sera of CRF patients, washed, and then assessed ouabain binding and ${ }^{86} \mathrm{Rb}$ uptake as we did for patients' cells removed before and after dialysis in vivo. When compared with normal or postdialysis sera, predialysis serum consistently inhibited pump-mediated ${ }^{86} \mathrm{Rb}$ uptake, without affecting the level of specific ouabain binding. This confirmed the presence of a serum factor and suggested, as did the data with the patients' own cells, that the inhibitor was not a ouabainlike molecule that bound tightly to the ouabain binding site on the $\mathrm{Na}, \mathrm{K}$ ATPase. In preliminary studies (Izumo, H., in preparation), there was an excellent correlation between the changes in ${ }^{86} \mathrm{Rb}$ uptake after serum exposure in vitro and those seen in erythrocytes of the dialyzed patients from whom the serum was derived. Studies to elucidate the chemical nature of the pump inhibitor described herein are currently in progress.

What is the mechanism of Na,K-pump inhibition? An obvious question relates to a possible role for changes in the level of erythrocyte sodium, since, under normal circumstances the enzyme functions near the Michaelis constant for sodium and therefore, the cell concentration of sodium could influence pump activity. Although measurements of cell $\mathrm{Na}$ are less precise than those of ${ }^{86} \mathrm{Rb}$ uptake, the available data do not suggest an important role for cell sodium in either the depressed pumping rate predialysis, or the increase in pumping rate postdialysis. Neither did the pumping rate correlate with pre- or post-dialysis values of serum $\mathrm{Na}, \mathrm{K}, \mathrm{pH}, \mathrm{BUN}$, or creatinine. Thus, the putative pump inhibitor of uremia would appear to be acting to inhibit pump function by a mechanism that is not currently defined.

Although a preliminary observation, we observed a significant correlation between the extent of rise in pump-mediated ${ }^{86} \mathrm{Rb}$ 
uptake and the amount of weight loss during hemodialysis. A similar correlation has recently been reported in preliminary form by using ouabain-inhibitable $\mathrm{Na}$ efflux as the means of assessing pump activity (24). Further studies to assess the independent effects of dialysis and ultrafiltration will be necessary to clarify the meaning of this relationship. If more extensive studies show that the extent of pump inhibition is related to the degree of volume overload, the inhibitor might be seen as a natriuretic factor, acting through inhibition of the $\mathrm{Na}, \mathrm{K}$ ATPase.

In conclusion, the novel aspects of this study are worthy of review. (a) We have shown, using each patient as his/her own control, that nearly all CRF patients on chronic hemodialysis have a defect in the activity of the Na,K pump. This prevalence exceeds the $25 \%$ figure reported by Welt et al. (4). (b) We have defined the nature of this prevalent defect to be a reduced $\mathbf{R b}$ pumping rate despite a normal number of pump units, a finding not previously documented. (c) We have provided evidence that this defect is caused by a serum factor that is present in pre-, but not post-dialysis serum. $(d)$ We have shown that the pump inhibition is acutely reversed by hemodialysis. In a limited number of patients previously reported (6), hemodialysis over a period of many weeks improved pump activity, but an immediate effect of dialysis has not been reported. (e) We suggest, through the correlation of pump disinhibition with weight loss during dialysis, that volume expansion might be a regulatory factor in the genesis of the $\mathrm{Na}, \mathrm{K}$ pump inhibitor.

Future studies will be necessary to determine the identity of the inhibitory factor, the precise mechanism by which it inhibits the $\mathrm{Na}, \mathrm{K}$ pump and the factors that regulate its synthesis and clearance. These studies could be important for our understanding of the pathogenesis of uremia, as well as our understanding of the regulation of the $\mathrm{Na}, \mathrm{K}-\mathrm{ATPase}$.

\section{Acknowledgments}

The authors would like to thank Dr. Franklin Epstein for many helpful discussions, and the staff of the Dialysis Unit at Beth Israel Hospital for their aid in carrying out the studies. We also would like to acknowledge Terri Wiseman for her help in the preparation of the manuscript.

Dr. Jeffrey Flier is the recipient of a Research Career Development Award AM00856-02 from the National Institutes of Health. This work was supported by grant AM28082-03 from the National Institutes of Health and a grant from the American Heart Association, 82-1029.

\section{References}

1. Glynn, I. M. 1968. Membrane adenosine triphosphatase and cation transport. Br. Med. Bull. 24:165-169.

2. Skou, J. C. 1973. The relationship of the $\left(\mathrm{Na}^{+}-\mathrm{K}^{+}\right)$-activated enzyme system to transport of sodium and potassium across the cell membrane. J. Bioenerg. 4:1-30.

3. Sweadner, K. J., and S. M. Goldin. 1980. Active transport of sodium and potassium ions: mechanism, function, and regulation. $N$. Engl. J. Med. 302:777-783.

4. Welt, L. G., J. R. Sachs, and T. J. Manus. 1964. An ion transport defect in erythrocytes from uremic patients. Trans. Assoc. Am. Phys. 77:169-181.

5. Cole, C. H., J. W. Balfe, and L. G. Welt. 1968. Induction of ouabain-sensitive ATPase defect by uremic plasma. Trans. Assoc. Am. Phys. 81:213-221.

6. Welt, L. G., E. K. M. Smith, M. J. Dunn, A. Czerwinski, H. Proctor, C. Cole, J. W. Balfe, and H. J. Gitelman. 1967. Membrane transport defect: the sick cell. Trans. Assoc. Am. Phys. 30:217-226.

7. Cole, H. 1973. Decreased ouabain-sensitive adenosine triphosphatase activity in the erythrocyte membrane of patients with chronic renal disease. Clin. Sci. Mol. Med. 45:775-784.

8. Villamil, M. F., V. Rettori, and C. R. Kleeman. 1968. Sodium transport by red blood cells in uremia. J. Lab. Clin. Med. 72(2):308317.

9. Kramer, H. J., D. Gospodinov, and F. Kruch. 1976. Functional and metabolic studies on red blood cell sodium transport in chronic uremia. Nephron. 16:344-358.

10. Swaminathan, R., G. Clegg, M. Cumberbatch, Z. Zareian, and F. MacKenna. 1982. Erythrocyte sodium transport in chronic renal failure. Clin. Sci. (Lond.). 62:489-494.

11. Cumberbatch, M., and D. B. Morgan. 1981. Relation between sodium transport and sodium concentration in human erythrocytes in health and disease. Clin. Sci. (Lond.). 60:555-564.

12. Edmondson, R. P. S., P. J. Hilton, N. F. Jones, J. Patrick, and R. D. Thomas. 1975. Leucocyte sodium transport in uremia. Clin. Sci. Mol. Med. 49:213-216.

13. Patrick, J., and N. F. Jones. 1974. Cell sodium, potassium and water in uremia and the effect of regular dialysis as studied in leucocytes. Clin. Sci. Mol. Med. 46:583-590.

14. Cotton, J. R., T. Woodman, N. W. Carter, and J. P. Knochel. 1979. Resting skeletal muscle membrane potential as an index of uremic toxicity. J. Clin. Invest. 63:501-506.

15. Kramer, H. J., A. Bocker, and F. Kruck. 1974. Inhibitor of intestinal Na,K-ATPase in experimental uremia. Clin. Chim. Acta. 50:1318.

16. Minkoff, L., G. Gaertener, M. Darab, C. Mercier, and M. L. Levin. 1972. Inhibition of brain sodium-potassium ATPase in uremic rats. J. Lab. Clin. Med. 80:71-78.

17. DeLuise, M., G. L. Blackburn, and J. S. Flier. 1980. Reduced activity of the red cell sodium-potassium pump in human obesity. $N$. Engl. J. Med. 303:1017-1022.

18. Gardner, J. D., and T. P. Conlon. 1972. The effect of sodium and potassium on ouabain binding by human erythrocyte. J. Gen. Phys. 60:609-629.

19. DeLuise, M., H. Izumo, E. E. Grace, and J. S. Flier. 1983. Effect of diet upon the erythrocyte Na,K pump. J. Clin. Endocrinol. Metab. 56:739-743.

20. Gardner, J. D., and D. R. Kino. 1973. Ouabain binding and cation transport in human erythrocytes. J. Clin. Invest. 52:1845-1851.

21. Schmalzing, G., E. Pfaff, and U. Breyer-Pfaff. 1981. Red cell ouabain sites, $\mathrm{Na}^{+}-\mathrm{K}^{+}$-ATPase and intracellular $\mathrm{Na}^{+}$. Life Sci. 29(4):371381.

22. Gruber, K. A., J. M. Whilaker, and V. M. Buckalew, Jr. 1980. Endogenous digitalis-like substance in plasma of volume-expanded dogs. Nature (Lond.). 287:743-745.

23. Woods, J. W., J. C. Parker, and B. S. Watson. 1983. Perturbation of sodium-lithium countertransport in red cells. N. Engl. J. Med. 308:1258-1261.

24. Krazesinski, J. M., and G. Rorive. 1983. Sodium-lithium countertransport in red cells. (Correspondence). N. Engl. J. Med. 309:987988. 